\title{
PROGRAM PENGEMBANGAN PRODUK UNGGULAN DAERAH (PPPUD) KERAJINAN TENUN SUTERA SENGKANG DI KABUPATEN WAJO BERBASIS KEARIFAN LOKAL SUKU BUGIS
}

\author{
Muhammad Ardi ${ }^{*}$, Muhammad Rakib², Faizal Amir ${ }^{3}$, Bakhrani A. Rauf ${ }^{4}$, \\ Alimuddin Sa'ban Miru ${ }^{5}$ \\ Universitas Negeri Makassar \\ *Penulis Korespodensi : $\underline{\text { m.ardi@unm.ac.id }}$
}

\begin{abstract}
Abstrak
Tujuan kegiatan PPPUD ini adalah: (1) Memperkenalkan kepada mitra jadwal perencanaan produksi yang efisien dan efektif; (2) Melatih mitra membuat jadwal perencanaan produksi yang efisien dan efektif; (3) Memperkenalkan kepada mitra desain motif kain tenun sutera yang berbasis pada kearifan lokal Suku Bugis; (4) Melatih mitra membuat desain, mengembangkan desain, dan menenun kain tenun sutera yang berbasis pada kearifan lokal Suku Bugis. Metode yang digunakan adalah sebgai berikut: (1) melakukan sosialisasi kepada Pemerintah Kabupaten Wajo dan industri mitra; (2) melatih dan mendampingi mitra membuat jadwal perencanaan produksi yang efisien dan efektif; (3) melatih dan mendampingi mitra membut desain, mengembangkan desain, dan menenun kain tenun sutera yang berbasis pada kearifan lokal Suku Bugis; (4) melakukan monitroing dan evaluasi. Hasil yang dicapai adalah sebagai berikut: (1) mitra mengenali dan terampil membuat jadwal perencanaan produksi yang efisien dan efektif; (2) mitra mengenali dan termpil membuat desain, mengembangkan desain, dan menenun motif kain tenun sutera yang berbasis pada kearifan lokal Suku Bugis.
\end{abstract}

Kata Kunci: Desain; Kain tenun; Kearifan loka; Suku Bugis; Sutera

\begin{abstract}
The objectives of this PPPUD activity are: (1) Introducing to partner an efficient and effective production planning schedule; (2) Training partner to make an efficient and effective production planning schedules; (3) Introducing silk-woven fabric design based on the local wisdom of the Bugis tribe to partner; (4) Training partner to design, develop designs, and weave silk fabrics based on local wisdom of the Bugis tribe. The methods used are as follows: (1) disseminating information to the Wajo Regency Government and partner industry; (2) train and assist partner in making efficient and effective production planning schedules; (3) train and assist partners in designing, developing designs, and weaving silk fabrics based on local wisdom of the Bugis tribe; (4) conducting monitoring and evaluation. The results achieved are as follows: (1) partners recognize and are skilled at making efficient and effective production planning schedules; (2) partners recognize and are skilled at making designs, developing designs, and weaving silk woven motifs based on local wisdom of the Bugis tribe.
\end{abstract}

Keywords: design;local wisdom; silk; the Bugis tribe; woven fabrics 


\section{PENDAhuluan}

Kabupaten Wajo yang ibu kotanya adalah Sengkang merupakan wilayah penghasil benang sutera dan kaintenun sutera di Provinsi Sulawesi Selatan. Kain tenun sutera, yakni sarung sutera dan baju sutera yang diproduksi oleh para pengrajin sutera di Kabupaten Wajo merupakan pakaian adat Suku Bugis dan Makassar yang dipakai pada acara pesta pernikahan, pesta adat, syukuran, upacara peringatan hari jadi kabupaten, upacara peringatan hari-hari besar nasional, dan upacara adat lainnya. Kain tenun sutera tidak terpisahkan dengan masyarakat Suku Bugis dan Makassar dari sisi budaya. Kain tenun sutera merupakan hasil kerajinan masyarakat Suku Bugis yang basisnya di Kabupaten Wajo, yakni di kota Sengkang. Oleh karena itulah kain tenun sutera Sengkang merupakan produk unggulan Kabupaten Wajo. Sutera menjadi simbol Kabupaten Wajo, yakni "Sengkang Kota Sutera".

Mitra PPPUD ini adalah UMKM Aminah Akil

Silk. Alasan yang mendasari adalah Aminah Akil Silk membutuhkan bimbingan dalam hal: (1) desain kain tenun sutera yang berbasis pada kearifan lokal Suku Bugis, untuk meningkatkan kuantitas dan kualitas produksi, (2) manajemen produksi.

Penelitian tentang Identifikasi Kondisi Sosial Ekonomi aan Keterampilan Penenun Sutera di Kabupaten Wajo (Muhammad Ardi, 2018), menemukan sebagai berikut: (1) pendidikan formal penenun adalah tammat SMP dan SMA, (2) penenun berasal dari keluarga petani setempat, (3) pengetahuan penenun tentang desain motif atau corak tenun kain sutera yang berbasis pada kearifan lokal Suku Bugis tergolong rendah, dan (4) keterampilan penenun membuat dan mengembangkan desain motif kain tenun sutera yang berbasis pada kearifan lokal Suku Bugis juga masih rendah.

Bahan baku mitra adalah benang sutera yang diproduksi di Kabupaten Wajo. Kualitas produksi benang sutera tergolong baik. Benang sutera tersedia cukup banyak di Kabupaten Wajo dan Kabupaten tetangga. Alat tenun yang dimiliki mitra adalah sebagai berikut: (1) alat tenun bukan mesin (ATBM) gedongan sebanyak enam (6) unit, dan (2) ATBM duduk sebanyak sebelas (11) unit. Kapasitas produksi satu ATBM dengan satu orang penenun rata-rata 4 sampai 5 meter dalam satu hari kain sarung atau kain kemeja.

Proses produksi dimulai dari: (1) pemilihan benang, (2) perwarnaan benang, (3) pemasangan benang yang sudah diwarnai Pada ATBM, yang selanjutnya disesuiakan ukuran ATBM, (4) membentangkan benang untuk ukuran panjang untuk digulung pada ATBM, (5) pemintalan benang untuk digulung pada alat peluru (caropeng dalam bahasa bugis) yang sudah diwarnai, dan (6) ATBM siap dioperasikan oleh penenun. Kontrol mitra terhadap proses produksi tergolong rendah. Kuantitas produksi mitra, yakni kain tenun sutera yang berbasis pada kearifan lokal Suku Bugis tergolong masih rendah.

Mitra mengalami kesulitan dalam meningkatkan produksi kain tenun sutera motif yang berbasis pada kearifan lokal Suku Bugis. Kontrol mitra terhadap kuantitas produksi tergolong rendah. Kualitas produksi dilihat dari sisi motif yang berbasis pada kearifan lokal Suku Bugis tergolong masih rendah. Kontrol mitra terhadap kualitas produksi masih rendah. Tenaga kerja penenun mitra saat ini berjumlah 16 orang. Pendidikan mereka adalah tamat SMP sebanyak 7 orang, dan tamat SMA sebanyak 9 orang.

Pengetahuan mitra tentang desain yang berbasis pada kearifan lokal Suku Bugis tergolong rendah. Keterampilan mereka membuat dan mengembangkan desain kain tenun sutera yang berbasis pada kearifan lokal Suku Bugis juga tergolong rendah. Tenaga kerja penenun mitra belum pernah mendapatkan pelatihan membuat desain kain tenun sutera motif yang berbasis pada kearifan lokal Suku Bugis.

Manajemen mitra pada aspek produksi kain tenun sutera sangat sederhana, yakni melakukan produksi berdasarkan kondisi produk yang terjual. Mitra belum memiliki perencanaan produksi secara rutin dan terjadwal. Perencanaan produksi hanya diperkirankan saja.

Tujuan kegiatan PPPUD ini adalah: (1) Memperkenalkan kepada mitra jadwal perencanaan produksi yang efisien dan efektif; (2) Melatih mitra membuat jadwal perencanaan produksi yang efisien dan efektif; (3) Memperkenalkan kepada mitra desain motif kain tenun sutera yang berbasis pada kearifan lokal Suku Bugis; (4) Melatih mitra membuat desain, mengembangkan desain, dan menenun kain tenun sutera yang berbasis pada kearifan lokal Suku Bugis.

Target luaran yang dicapai adalah meningkatnya: (1) pengetahuan dan keterampilan mitra membuat jadwal perencanaan produksi; (b) pengetahuan dan keterampilan mitra membuat dan mengembangkan desain kain tenun sutera motif yang berbasis pada kearifan lokal Suku Bugis; (c) kuantitas dan kualitas produksi kain tenun sutera motif yang berbasis pada kearifan lokal Suku Bugis; dan (d) jumlah dan jenis motif ptoduk kain tenun sutera yang berbasis pada kearifan lokal Suku Bugis.

Teori yang mendasari PPPUD diuraikan sebagai berikut. Kain sutera terdiri dari susunan serat-serat yang terbentuk dari ulat yang berubah menjadi kepompong, merupakan kain yang memiliki tekstur, lembut, mulus dan berkilau, yang digunakan pada acara resmi (https://inspiring.id/fakta-kain-sutra-yang-harusanda-ketahui/). Menurut Kamus Besar Bahasa Indonesia (2008), sutera adalah benang halus dan lembut yang berasal dari kepompong ulat sutera. Sutera merupakan serat protein alami yang beberapa jenisnya dapat ditenun menjadi tekstil. Jenis sutera yang paling dikenal adalah sutera yang diperoleh dari kepompong yang dihasilkan larva ulat sutera kertau (bombyx mori). 
Anggraini dan Kirana (2014) menyatakan
bahwa desain merupakan suatu proses pengorganisasian unsur garis, bentuk ukuran, warna, tekstur, bunyi, cahaya, aroma dan unsur-unsur desain lainnya, sehingga tercipta suatu hasil karya tertentu. Kamus Besar Bahasa Indonesia (2008), desain adalah gagasan awal, rancangan, perencanaan pola susunan, kerangkabentuk suatu bangunan, motif bangunan, pola bangunan, corak bangunan. Menurut Sjafi'i (2001), desain adalah terjemahan fisik mengenai aspek sosial, ekonomi, dan tata hidup manusia, serta merupakan cerminan budaya zamannya.

Setyo Harini (2016) menyatakan bahwa produksi adalah menciptakan, menghasilkan, dan membuat suatu produk yang memiliki nilai ekonomi dan sosial. Sukirno (2005) menyatakan bahwa produksi adalah suatu kegiatan yang mengubah input menjadi output. Anoraga (2005) menyatakan bahwa produksi didefenisikan sebagai penciptaan guna, dimana guna berarti kemampuan barang atau jasa untuk memenuhi kebutuhan manusia.

Tambunan (2012) menyatakan bahwa UMKM adalah unit usaha produktif yang berdiri sendiri, yang dilakukan oleh orang perorangan atau Badan Usaha di semua sektor ekonomi. Wahyudin (2013) ${ }^{[10]}$ menyatakan bahwa UMKM di Indonesia menempati porsi sekitar 99\%, artinya hampir seluruh usaha di Indonesia merupakan usaha kecil, hanya $1 \%$ saja usaha menengah dan besar.

\section{METODE}

Tahapan dalam melaksanakan kegiatan PPPUD sebagai berikut.

A. Melakukan Perizinan dan Persiapan Lokasi.

Untuk memulai kegiatan PPPUD, maka terlebih dahulu menyampaikan surat permohonan izin lokasi PPPUD, yakni pada Pemerintah Kabupaten Wajo untuk memperoleh izin lokasi. Selanjutnya dilakukan persiapan lokasi. Persiapan lokasi berfokus pada UMKM Mitra.

B. Melakukan Sosialisasi

Sosialisasi dilakukan pada Dinas Perindustrian Kabupaten Wajo dan mitra. Materi sosialisasi difokuskan pada: (1) jadwal perencanaan produksi, (2) desain kain sutera motif yang berbasis pada kearifan lokal Suku Bugis, dan (3) peningkatan kuantitas dan kualitas produksi. Strategi yang digunakan adalah melakukan diskusi dan tanya jawab.

C. Memperkenalkan Materi

Kegiatan yang dilakukan untuk memperkenalkan materi kepada mitra adalah sebagai berikut: memperkenalkan langsung jadwal perencanaan produksi yang efisien dan efektif, desain kain tenun sutera motif yang berbasis pada kearifan lokal Suku Bugis. Strategi yang digunakan adalah diskusi dan tanya jawab. Selanjutnya dilakukan penyuluhan kepada mitra. Kegiatan yang dilakukan adalah memberikan materi kepada mitra tentang jadwal perencanaan produksi, desain kain tenun sutera motif yang berbasis pada kearifan lokal Suku Bugis. Strategi yang digunakan adalah ceramah, diskusi, dan tanya jawab.

D. Melaksanakan Pelatihan

Kegiatan pelatihan adalah sebagai berikut: (1) Melatih mitra membuat jadwal perencanaan produksi yang efisien dan efektif; (2) Melatih mitra membuat desain motif kain tenun sutera yang berbasis pada kearifan lokal suku Bugis, yaitu: Pucu Rebbung, Caca Wali, Balo Loban, Balo Renni, Balo Tettong, dan Balo Bombang. Strategi yang digunakan: demonstrasi, diskusi, dan tanya jawab.

E. Melakukan Pendampingan

Kegiatan yang dilakukan adalah sebagai berikut: (1) Mendampingi mitra membuat jadwal prencanaan produksi yang efisien dan efektif; (2) Mendampingi mitra menerapkan desain untuk meningkatkan kuantitas dan kualitas produksi, yakni menenun kain sutera motif: Pucu Rebbung, Caca Wali, Balo Lobang, Balo Renni, Balo Tettong, dan Balo Bombang. Strategi yang digunakan: diskusi dan tanya jawab.

F. Melakukan Monitoring dan Evaluasi Program Monitoring dilakukan pada saat mitra diberdayakan. Strategi yang digunakan: memihat langsung mitra membuat jadwal perencanaan produksi, membuat dan menerapkan desain sebagai upaya meningkatkan kuantitas dan kualitas produksi kain tenun sutera motif: Риси Rebbung, Caca Wali, Balo Lobang, Balo Renni, Balo Tettong, dan Balo Bombang. Evaluasi dilakukan pada saat pemberdayaan telah selesai yang bertujuan untuk menilai pengetahuan dan keterampilan mitra. Stategi yang digunakan: menilai pengetahuan dan keterampilan membuat jadwal perencanaan produksi, membuat dan menerapkan desain kain tenun sutera sebagai upaya meningkatkan kuantitas dan kualitas produksi kain tenun sutera motif: Pucu Rebbung, Caca Wali, Balo Lobang, Balo Renni, Balo Tettong, dan Balo Bombang.

\section{HASIL DAN PEMBAHASAN}

\section{A. Kegiatan Persiapan dan Sosialisasi}

Kegiatan persiapan dan sosialisasi dilakukan dengan tujuan: (1) melakukan perizinan kepada pemerintah Kabupaten Wajo dalam hal ini Dinas Perindustrian Kabupaten Wajo, (2) melakukan kegiatan sosialisi tentang program yang akan dilakukan kepada Dinas Prindustrian Kabupaten Wajo, (3) mempersiapkan Mitra, dalam hal ini tempat pelatihan, alat yang digunakan, bahan yang digunakan, dan tenaga kerja penenun, (4) mengsosialisasi kegiatan yang akan 
dilakukan kepada mitra terutama kepada tenaga kerja penenun.

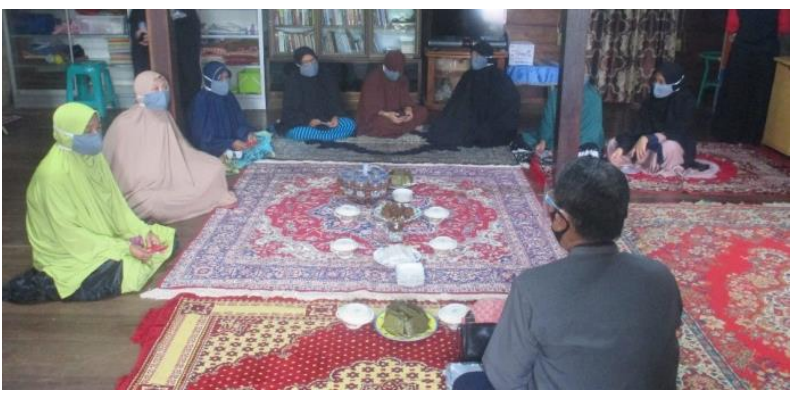

Gambar 1. Kegiatan Sosialisasi

\section{B. Jadwal Produksi} berikut:

Kegiatan yang dilakukan adalah sebagai

1. Memperkenalkan kepada mitra jadwal perencanaan produksi yang efisien dan efektif.

2. Memberikan penyuluhan kepada mitra tentang jadwal perencanaan produksi yang efisien dan efektif.

3. Melatih mitra membuat jadwal perencanaan produksi yang efisien dan efektif.

4. Mendampingi mitra membuat jadwal perencanaan produksi yang efisien dan efektif.

Keempat kegiatan ini dilakukan dengan uraian sebagai berikut: (a) mitra tidak mengalami kesulitan dalam memahami jadwal perencanaan produksi yang efisien dan efektif setelah diperkenalkan oleh tim pelaksana, (b) mitra berdiskusi dengan tim pelaksana untuk merencanakan jadwal produksi sesuai kondisi lapangan, (c) mitra membuat jadwal produksi, didampingi oleh tim pelaksana dan berdiskusi dengan tim pelaksana.

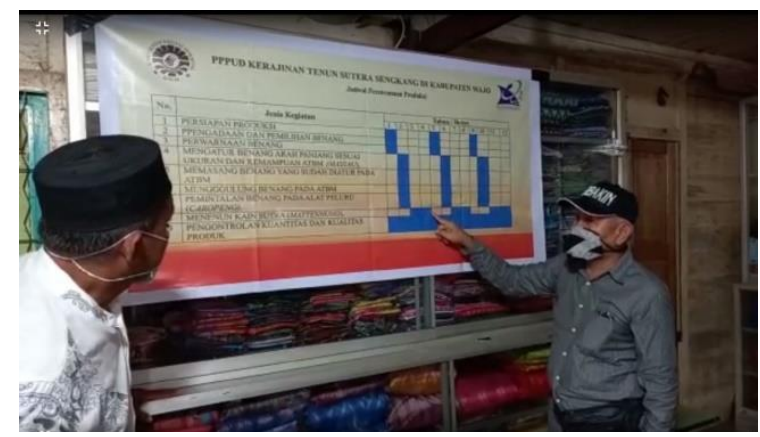

Gambar 2. Menjelaskan Jadwal Produksi

Setelah melakukan kegiatan evaluasi atau penilaaian, maka hasil yang dicapai adalah sebagai berikut:

1. Mitra mengenali perencanaan jadwal produksi yang efisien dan efektif.

2. Mitra memiliki pengetahuan yang luas tentang jadwal perencanaan produksi yang efisien dan efektif.
3. Mitra memiliki keterampilan dasar membuat jadwal perencanaan produksi yang efisien dan efektif.

4. Mitra memiliki keterampilan yang tinggi membuat jadwal perencanaan produksi yang efisien danefektif.

Luaran yang dicapai adalah satu buah jadwal perencanaan produksi yang dipajang pada tempat kerja mitra, sebagai pedoman bagi mitra untuk melakukan kegiatan produksi kain tenun sutera yang berbasis pada kearifan lokal Suku Bugis.

\section{Meningkatkan Kuantitas dan Kualitas Kain Tenun Sutera} berikut:

Kegiatan yang dilakukan adalah sebagai

1. Memperkenalkan kepada mitra desain motif kain tenun sutera yang berbasis pada kearifan lokal Suku Bugis, yakni: Риси Rebbung, Caca Wali, Balo Lobang, Balo Renni, Balo Tettong, dan Balo Bombang.

2. Memberikan penyuluhan kepada mitra tentang desain kain tenun sutera motif yang berbasis pada kearifan lokal Suku Bugis.

3. Melatih mitra membuat dan mengembangkan desain kain tenun sutera yang berbasis pada kearifan lokal Suku Bugis.

4. Mendampingi mitra menerapkan desain dalam bentuk menenun motif kain sutera yang berbasis pada kearifan lokal Suku Bugis.

5. Membantu mitra untuk pengadaan benang sutera yang memiliki kualitas yang baik, untuk mempercepat peningkatan kuantitas dan kualitas produksi motif kain tenun sutera yang berbasis pada kearifan lokal Suku Bugis.

6. Mendampingi mitra pada saat menenun motif kain untuk meningkatkan kuantitas dan kualitas produksi kain tenun sutera yang berbasis pada kearifan lokal Suku Bugis.

Keenam kegiatan ini dilakukan dengan uraian sebagai berikut:

1. Mitra tidak mengalami kesulitan mengenali desain motif kain tenun sutera yang berbasis pada kearifan lokal Suku Bugis, yakni: Pucu Rebbung, Caca Wali, Balo Lobang, Balo Renni, Balo Tettong, dan Balo Bombag.

2. Mitra tidak mengalami kesulitan memahami desain motif kain tenun sutera yang berbasis pada kearifan lokal Suku Bugis, yakni: Pucu Rebbung, Caca Wali, Balo Loban, Balo Renni, Balo Tettong, dan Balo Bombang.

3. Mitra dapat mengembangkan desain kain tenun sutera yang berbasis pada kearifan lokal Suku Bugis yakni: Pucu Rebbung, Caca Wali, Balo Loban, Balo Renni, Balo Tettong, dan Balo Bombang, setelah melakukan diskusi dengan tim pelaksana.

4. Mitra dapat menerapkan desain dan mengembangkan desain dalam bentuk menenun 
motif kain sutera yang berbasis pada kearifan lokal Suku Bugis, yakni: Pucu Rebbung, Caca Wali, Balo Lobang, Balo Renni, Balo Tettong, dan Balo Bombang.

5. Mitra memiliki benang sutera yang berkualitas baik, untuk mempercepat peningkatan kuantitas dan kualitas produksi motif kain tenun sutera yang berbasis pada kearifan lokal Suku Bugis yakni: Pucu Rebbung, Caca Wali, Balo Lobang, Balo Renni, Balo Tettong, dan Balo Bombang.

6. Mitra tidak mengalami kesulitan menerapkan desain dan mengembangkan desain dalam bentuk menenun motif kain sutera yang berbasis pada kearifan lokal Suku Bugis, yakni: Pucu Rebbung, Caca Wali, Balo Lobang, Balo Renni, Balo Tettong, dan Balo Bombang setelah didampingi. Dalam proses pendampingan terjadi diskusi tentang makna dan asal usul Pucu Rebbung, Caca Wali, Balo Lobang, Balo Renni, Balo Tettong, dan Balo Bombang.

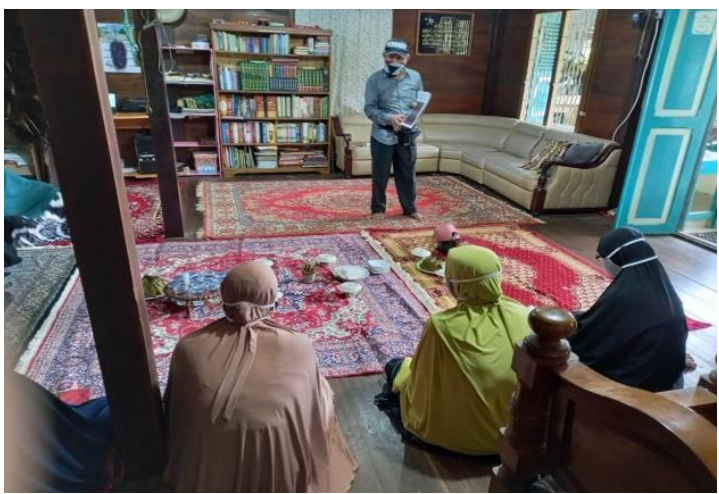

Gambar 3. Memperkenalkan Berbagai Macam Desain Kain Tenun Sutera Motif yang Berbasis Kearifan Lokal Suku Bugis

Setelah melakukan kegiatan evaluasi atau penilaian, maka hasil yang dicapai adalah sebagai berikut:

1. Mitra mengenali desain motif kain tenun sutera yang berbasis pada kearifan lokal Suku Bugis, yakni: Pucu Rebbung, Caca Wali, Balo Lobang, Balo Renni, Balo Tettong, dan Balo Bombang.

2. Mitra memiliki pengetahuan tentang desain motif kain tenun sutera yang berbasis pada kearifan lokal Suku Bugis, yakni: Pucu Rebbung, Caca Wali, Balo Lobang, Balo Renni, Balo Tettong, dan Balo Bombang.

3. Mitra memiliki ketempilan membuat desain dan mengembangkan desain motif kain tenun sutera yang berbasis pada kearifan lokal Suku Bugis, yakni: Pucu Rebbung, Caca Wali, Balo Lobang, Balo Renni, Balo Tettong, dan Balo Bombang.

4. Mitra memiliki ketempilan menenun desain desain motif kain tenun sutera yang berbasis pada kearifan lokal Suku Bugis, yakni: Pucu Rebbung, Caca Wali,
Balo Lobang, Balo Renni, Balo Tettong, dan Balo Bombang.

5. Mitra memiliki benang sutera yang cukup dan berkualitas untuk melakukan kegiatan peningkatan kuantitas dan kualitas motif kain tenun sutera yang berbasis pada kearifan lokal Suku Bugis, yakni: Pucu Rebbung, Caca Wali, Balo Lobang, Balo Renni, Balo Tettong, dan Balo Bombang.

6. Mitra memiliki ketempilan menenun, meningkatkan kuantitas, dan kualitas motif kain tenun sutera yang berbasis pada kearifan lokal Suku Bugis, yakni: Pucu Rebbung, Caca Wali, Balo Lobang, Balo Renni, Balo Tettong, dan Balo Bombang.

Luaran yang dicapai adalah sebagai berikut:

1. Motif atau corak kain tenun sutera Pucu Rebbung untuk kain sarung, 8 sampai 12 sarung.

2. Motif atau corak kain tenun sutera Pucu Rebbung kombinasi Caca Wali untuk kain sarung, 8 sampai 12 sarung.

3. Motif atau corak kain tenun sutera Balo Lobang kombinasi Caca Wali, untuk kain sarung, 8 sampai 12 sarung.

4. Motif atau corak kain tenun sutera Balo Tettong kombinasi Caca Wali, untuk kain kemeja,8 sampai 12 kemeja.

5. Motif atau corak kain tenun sutera Caca Wali kombinasi Balo Renni, untuk kain kemeja,8 sampai 12 kemeja.

6. Motif atau corak kain tenun sutera Balo Bombang untuk kain kemeja,8 sampai 12 kemeja.

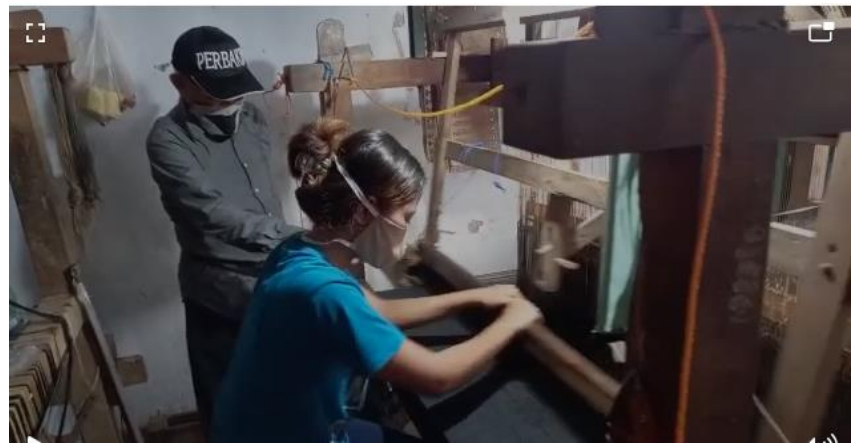

Gambar 4. Pengrajin Mitra Sedang Menenun Desain

Kain Tenun Sutera yang Berbasis pada Kearifan Lokal Suku Bugis 


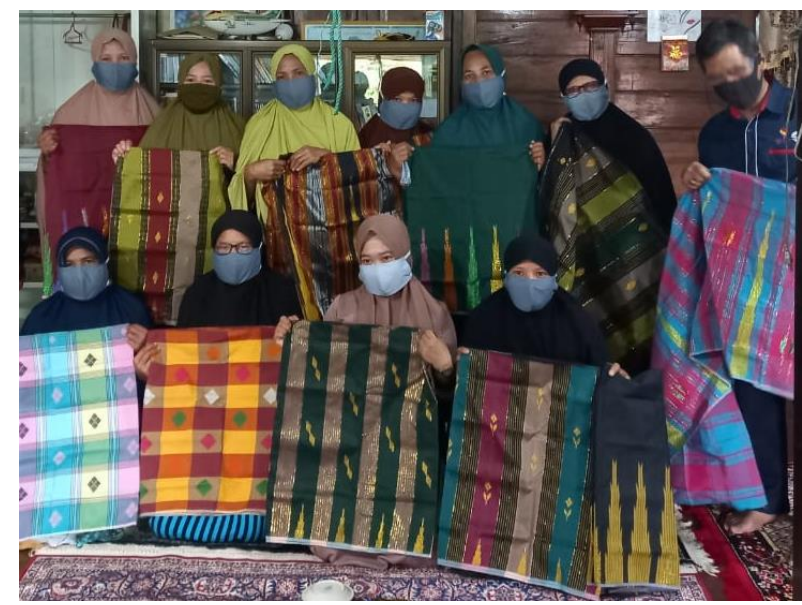

Gambar 5. Hasil Produksi Kain Tenun Sutera Motif yang Berbasis pada Kearifan Lokal Suku Bugis

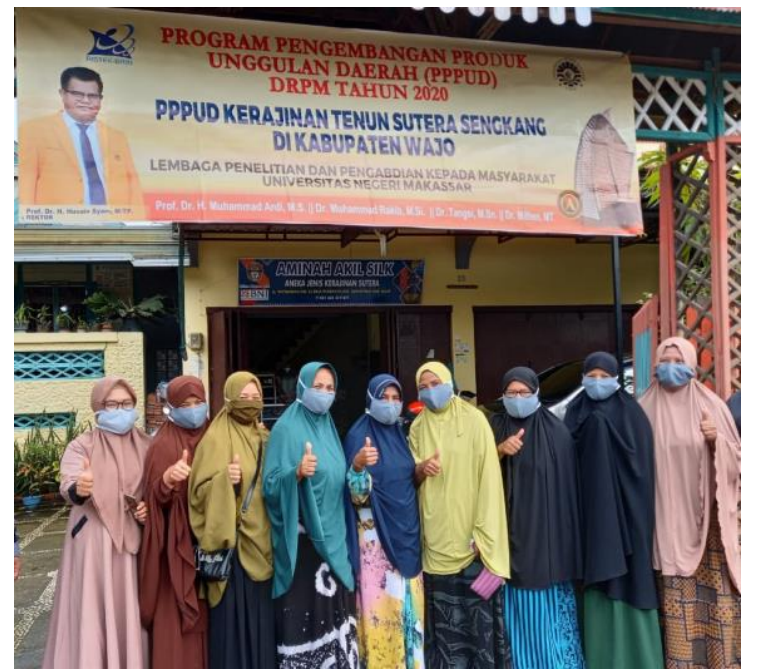

Gambar 6 . Foto Bersama Para Pengrajin Sutera Mitra

\section{KESIMPULAN}

1. Mitra mengenali, memiliki pengetahuan tentang perencanaan jadwal produksi dan terampil membuat jadwal perencanaan produksi yang efisien dan efektif.

2. Mitra mempedomani jadwal produksi yang telah dibuat dalam melakukan kegiatan produksi motif kain tenun sutera yang berbasis pada kearifan lokal Suku Bugis, yakni: Pucu Rebbung, Caca Wali, Balo Lobang, Balo Renni, Balo Tettong, dan Balo Bombang.

3. Mitra mengenali dan memiliki pengetahuan tentang desain motif kain tenun sutera yang berbasis pada kearifan lokal Suku Bugis, yakni: Pucu Rebbung, Caca Wali, Balo Lobang, Balo Renni, Balo Tettong, dan Balo Bombang.

4. Mitra memiliki ketempilan membuat, mengembangkan, dan terampil menenun, meningkatkan kuatitas dan kualitas motif kain tenun sutera yang berbasis pada kearifan lokal Suku Bugis, yakni: Pucu Rebbung, Caca Wali,
Balo Lobang, Balo Renni, Balo Tettong, dan Balo Bombang.

\section{UCAPAN TERIMA KASIH}

Ucapan terima kasih disampaikan masingmasing kepada:

1. Mensristek/BRIN dan Dirjen Dikti atas pendanaan kegiatan PPPUD sebagi bentuk pembinaan dosen di Perguruan Tinggi

2. Rektor Universitas Negeri Makassar atas izin, pembinaannya, dan motivasinya sehingga kegiatan Tri Dharma Pergurun Tinggi ini terlaksana dengan baik.

3. Ketua Lembaga Penelitian dan Pengabdian kepada Masyarakat (LP2M) Universitas Negeri Makassar atas dukungan dan arahannya melakukan kegiatan PPPUD ini dengan baik.

4. Pemereintah Kabupaten Wajo atas dukungandan pemberian izin untuk melakukan keggiatan PPPUD.

5. Mitra PPPUD atas partisipasi dan kerja samanya.

6. Seluruh anggota tim pelaksana kegiatan PPPUD atas kerja samanya yang baik.

7. Seluruh pihak yang telah berpartisipasi dalam kegiatan PPPUD ini yang tidak sempat disebutkan satu persatu.

Semoga apa yang telah dilakukan oleh semua pihak dalam mensukseskan kegiatan PPPUD ini dapat memberi manfaat yang sebesar-besarnya bagi Masyarakat, Bangsa dan Negara.

\section{DAFTAR PUSTAKA}

[1] Muhammad Ardi, 2018. Identifikasi Kondisi Sosial Ekonomi dan Keterampilan Penenun Sutera di Kabupaten Wajo. Laporan Penelitian. Makassar: Lembaga Penelitian Uniersitas Negeri Makassar.

[2] Anonim. 2020. Fakta Kain Sutra yang Harus Anda Ketahui. (https://inspiring.id/ fakta-kainsutra-yang-harus-anda-ketahui/), diakses 11 Agustus 2020.

[3] Kamus Besar Bahasa Indonesia. 2008. Jakarta: Balai Pustaka

[4] Anggraini, Lia \& Kirana Nathalia. 2014. Desain Komuikasi Visual, Dasar-dasar Panduan Untuk Pemula. Bandung: Nuansa Cendekia.

[5] Sjafi'I, Akhmad. 2001. Nirmana. Surakarta: STSI Press

[6] Setyo Harini. 2016. Peningkatan Pendapatan Dan Produksi Pembudidaya Lele Di Kecamatan Genteng Kabupaten Banyuwangi. Tesis. 
Jember: Program Pasca Sarjana Fakultas Ekonomi Dan Bisnis Universitas Jember.

[7] Sukirno, Sadono, 2005. Mikro Ekonomi Teori Pengantar. Edisi Ketiga. Jakarta: Raja Grafindo Persada.

[8] Anoraga, Pandji. 2005, Manajemen Bisnis. Cetakan Ketiga. Jakarta: Rineka Cipta

[9] Tambunan, T.H Tulus. 2012. Usaha Mikro Kecil dan Menengah di Indonesia: Isu-isu Penting. Jakarta: LP3ES.

[10] Wahyudin, Dian. 2013. Peluang atau Tantangan Indonesia MenujuASEAN Economic Community 2015. Semarang: Lembaga Penerbit Universitas Diponegoro. 